\title{
Early uterine development in pigs
}

\author{
F. F. Bartol ${ }^{1}$, A. A. Wiley ${ }^{1}$, T. E. Spencer ${ }^{1 *}$, J. L. Vallet ${ }^{2}$ and \\ R. K. Christenson ${ }^{2}$ \\ 'Department of Animal and Dairy Sciences, Aubum University, AL 36849-5415, USA; and \\ ${ }^{2}$ US Department of Agriculture, Agricultural Research Service, Roman L. Hruska US Meat Animal \\ Research Center, PO Box 166, Clay Center, NE 68933-0166, USA
}

The capacity of pig uterine tissues to recognize and respond to maternal and conceptus signals determines whether pregnancy can be established and defines the environment in which embryonic and fetal growth occur. Limits of uterine capacity may be defined genetically. However, the extent to which functional uterine capacity approaches genetic potential may be determined, in part, by the success of organizational events associated with growth, morphogenesis and cytodifferentiation of uterine tissues. It is important, therefore, that these events be identified and evaluated with respect to their potential effect on adult uterine function. Histogenesis of the pig uterus begins prenatally, but is completed postnatally. Transformation of the uterine wall from histoarchitectural infancy to maturity occurs between birth and day 120 . Morphogenetic events characteristic of the first 60 days of neonatal life proceed normally in gilts ovariectomized at birth. These events include appearance and proliferation of uterine glands, development of endometrial folds, and growth of the myometrium. Endometrial development during this period involves alterations in patterns of epithelial and stromal DNA synthesis, coordinated changes in the distribution and biosynthesis of extracellular matrix glycosaminoglycans and cell surface glycoconjugates, and specific alterations in patterns of uterine protein secretion. The ovary-independent, spatially coordinated nature of these events suggests that neonatal uterine development is regulated locally via dynamic cell-cell and cell-extracellular matrix interactions. The extent to which such potentially critical interactions must be preserved to ensure developmental success remains unknown. However, the normal pattern of ovary-independent cellular and molecular events associated with development of the uterine wall was disrupted by treating neonatal gilts with oestradiol valerate, and daily administration of oestrogen to gilts from birth to day 13 did not affect ovulation rate, but did reduce embryonic survival by $22 \%$ on day 45 of gestation in adults that were exposed to oestrogen neonatally. These observations support the idea that some organizational events associated with development of the neonatal uterine wall must be allowed to proceed without interruption to ensure that adult uterine function is not compromised. Efforts to identify specific developmental determinants of uterine capacity may be facilitated by examining the consequences of xenobiotically induced interruption of uterine development on adult uterine function. Such studies may also contribute to identification of uterine factors affecting embryonic survival and fetal growth. 


\section{Introduction}

In pigs, establishment of pregnancy and maintenance of an embryotrophic uterine environment depend upon endometrial responses to both maternal and conceptus signals (Bazer, 1992). Thus, the ability of uterine tissues to recognize and integrate specific systemic and local signals determines whether pregnancy can become established and defines the environment in which embryonic and fetal growth occur. The quality of this environment dictates not only the number of conceptuses that can be supported at a specific stage of gestation in litter-bearing species such as pigs, but can also have profound effects on conceptus growth and postnatal phenotype (Christenson et al., 1987; Roberts and Bazer, 1988; Cowley et al., 1989; Pomp et al., 1989; Atchley et al., 1991). The extent to which uterine tissues function to optimize these traits contributes to uterine capacity (Christenson et al., 1987; Bazer et al., 1988).

The existence of hyperprolific breeds of pig, such as the Chinese Meishan, and development of strains such as the hyperprolific Large White (Legault, 1985), indicate that limits of uterine capacity may be defined genetically. Functionally, however, the observation that multiparous sows will carry more embryos to term than do gilts (Legault, 1985; First and Eyestone 1988) supports the idea that phenotypic uterine capacity may be determined, in part, by the developmental history of the uterus itself. This idea is reinforced by data indicating that adult urogenital tract function can be compromised if development is interrupted pharmacologically during fetal or early neonatal life (Sananes et al., 1980; Forsberg, 1988; Mori and Iguchi, 1988; Halling and Forsberg, 1990). The success of organizational events associated with growth, morphogenesis and cytodifferentiation of uterine tissues may determine the potential of the adult uterus to respond to activational cues necessary to optimize prolificacy. Consequently, it is important that these events be defined and evaluated with respect to their potential to affect adult uterine function and reproductive efficiency.

Mechanisms regulating growth, development and differentiation of uterine tissues during fetal and neonatal periods are poorly defined for pigs, but may prove to be critical determinants of uterine capacity. The purpose of this report is to: (1) review events characteristic of early uterine development, (2) summarize recent observations pertaining to cellular and molecular events associated with normal uterine growth and development in neonatal pigs and (3) introduce data indicating that some neonatal developmental events may be required to proceed without interruption to ensure that adult porcine uterine function is not compromised.

\section{Embryonic Origins, Growth and Histogenesis of the Pig Uterus}

The uterus develops from the paramesonephric (Mullerian) ducts, a pair of completely mesodermal tubes that arise from invaginations of coelomic epithelium on the lateral aspects of the urogenital ridges (Marion and Gier, 1971; Cunha, 1989; Mossman, 1989). These ducts grow towards the midline, meet and begin to fuse at their caudal ends (Mossman, 1980). The degree of fusion that occurs is species specific and defines the gross morphological characteristics of the adult uterus (Davies, 1967; Mossman, 1980). In pigs complete caudal fusion of the paramesonephric ducts involves only a short segment of the ductal lumina. Consequently, the bicornuate pig uterus consists, grossly, of a short uterine body connecting long tubular uterine horns (Mossman, 1980, 1989).

Histologically, the endometrium and both inner circular and outer longitudinal smooth muscle layers of the myometrium develop from unorganized, undifferentiated mesenchyme (Marion and Gier, 1971; Brody and Cunha, 1989a). Organizational events leading to differentiation of the mesenchyme into endometrial and myometrial tissue layers, and development of relevant endometrial structure begin during fetal life and are completed postnatally in most species, including pigs. However, events characteristic of uterine histogenesis are ordered and include: (1) stratification and spatial orientation of subepithelial mesenchymal cells, leading to establishment of a dense subepithelial layer of stromal cells and a more loosely organized network of fibroblasts in the deeper stroma adjacent to the developing myometrium, (2) organization and differentiation of a prospective myometrium, and (3) coordinated development of species-specific endometrial histoarchitecture. Appearance and proliferation of coiled tubular uterine glands, characteristic of the endometrium in all viviparous mammals (Mossman, 1980), is a postnatal event in pigs. Development of the inner circular myometrial layer, derived from cells of the intermediate layer of ductal mesenchyme, precedes that of the outer longitudinal myometrium, which is 
derived from subperimetrial mesenchyme (Bal and Getty, 1970; Marion and Gier, 1971; Mossman, 1980; Atkinson et al., 1984; Konishi et al., 1984; Wiley et al., 1987; Brody and Cunha, 1989a).

\section{Postnatal uterine growth and morphogenesis}

Growth of the pig uterus and development of the uterine wall between birth (day 0 ) and puberty have been characterized grossly (Dyck, 1980; Dyck and Swierstra, 1983; Evans et al., 1988; Wu and Dziuk, 1988) and histologically (Hadek and Getty, 1959; Bal and Getty, 1970; Erices and Schnurrbusch, 1979; Dyck, 1980; Spencer et al., 1993a). Uterine wet weight increases slowly but linearly during the first 8-10 weeks of neonatal life, and is directly related to increasing age and body weight (Dyck and Swierstra, 1983). Thereafter, between day 60 and day 80 , both uterine weight and uterine growth rate increase abruptly and continue to increase until near the time of puberty (Dyck, 1980; Dyck and Swierstra, 1983; Evans et al., 1988; Wu and Dziuk, 1988). Dyck (1980) and Dyck and Swierstra (1983) suggested that the dramatic increase in uterine growth after approximately day 70 reflects uterotrophic effects of ovarian oestrogen. Peripheral plasma oestradiol concentrations increase during this period (Evans et al., 1988). Consistent with these observations, Wu and Dziuk (1988) demonstrated that ovariectomy of neonatal gilts on day 20 did not affect uterine growth until after day 60 , when uteri of intact controls were larger and grew more rapidly. These data were recently confirmed and extended by a study in which uteri ( $n=5$ per day) were obtained on days $0,15,30,60,90$ and 120 from intact gilts and gilts ovariectomized on the day of birth (Bartol and Wiley, unpublished observations). Overall, uterine weight and both endometrial and myometrial thicknesses did not differ, and increased $(P<0.01)$ in a similar way in intact and ovariectomized gilts before day 60 , but in intact gilts after day 60 these values were greater and increased $(P<0.01)$ more rapidly (Fig. 1). However, uteri of ovariectomized gilts did continue to grow until day 120. Wu and Dziuk (1988) also reported uterine growth for ovariectomized gilts between day 20 and day 140. Moreover, Evans ef al. (1988) found no clear relationship between patterns of growth of adrenal or thyroid glands and gross aspects of reproductive tract growth in gilts between weaning at three weeks of age and puberty. These data suggest that growth of the pig uterus requires neither ovarian nor, possibly, adrenal or thyroid support between birth and day 60 . However, patterns of uterine growth and histogenesis observed for gilts ovariectomized at or shortly after birth make it clear that extra-ovarian factors support these processes throughout the first 120-140 days of life.

Transformation of the pig uterine wall from histoarchitectural infancy to maturity occurs between birth and postnatal day 120 (Hadek and Getty, 1959; Bal and Getty, 1970; Erices and Schnurrbusch, 1979; Dyck and Swierstra, 1983). Dziuk and Gehlbach (1966) demonstrated that immature gilts that were induced to ovulate and bred artificially on or after neonatal day 110 could become pregnant and maintain corpora lutea for at least 23 days. Thus, uterine tissues not only become organized structurally, but also acquire the capacity to respond to conceptus signals during this period.

Significant remodelling of the pig uterine wall occurs during the first eight weeks of neonatal life (Fig. 2). Neither endometrial nor myometrial tissues are completely differentiated at birth (Bal and Getty, 1970). Endometrial glands, absent at birth, develop from shallow epithelial depressions, evident at intervals along the surface of the uterine lumen, into coiled, branched epithelial tubes that extend radially from the luminal surface, through endometrial stroma, to the adluminal border of the myometrium (Spencer $e$ t al., 1993a). Uterine folds, evident by day 30 as luminal protrusions of glandular endometrium, are well developed by day 60 (Hadek and Getty, 1959; Bal and Getty, 1970; Spencer et al., 1993a). A developing inner circular layer of myometrial cells is easily distinguished from endometrial stroma at birth; however, the outer longitudinal layer of smooth muscle is indistinct. Development of this layer lags behind that of the inner circular myometrium and proceeds in a cranial direction from the area of the uterine body toward the tips of the uterine homs (Bal and Getty, 1970). Overall, histoarchitectural features characteristic of the mature pig uterine wall are apparent, although not completely developed, by neonatal day 30 (Bal and Getty, 1970; Spencer et al., 1993a).

Considered together, these observations indicate that extensive remodelling of the pig uterine wall occurs during a period associated with ovary-independent uterine growth. Similar patterns of ovaryindependent uterine development were reported for the neonatal ewe by Bartol et al. (1988a,b), and for the mouse by others (Ogasawara et al., 1983; Bigsby and Cunha, 1985). Data indicating that uterine histogenesis proceeds normally in neonatally ovariectomized, adrenalectomized mice were interpreted to 


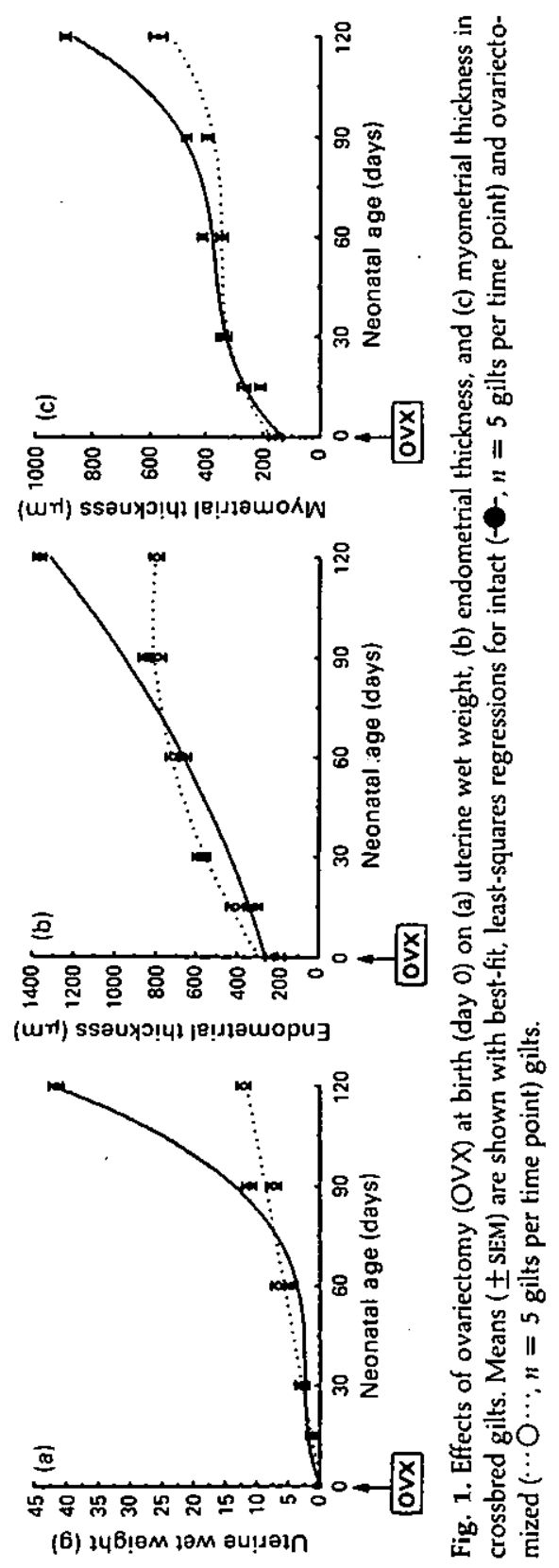



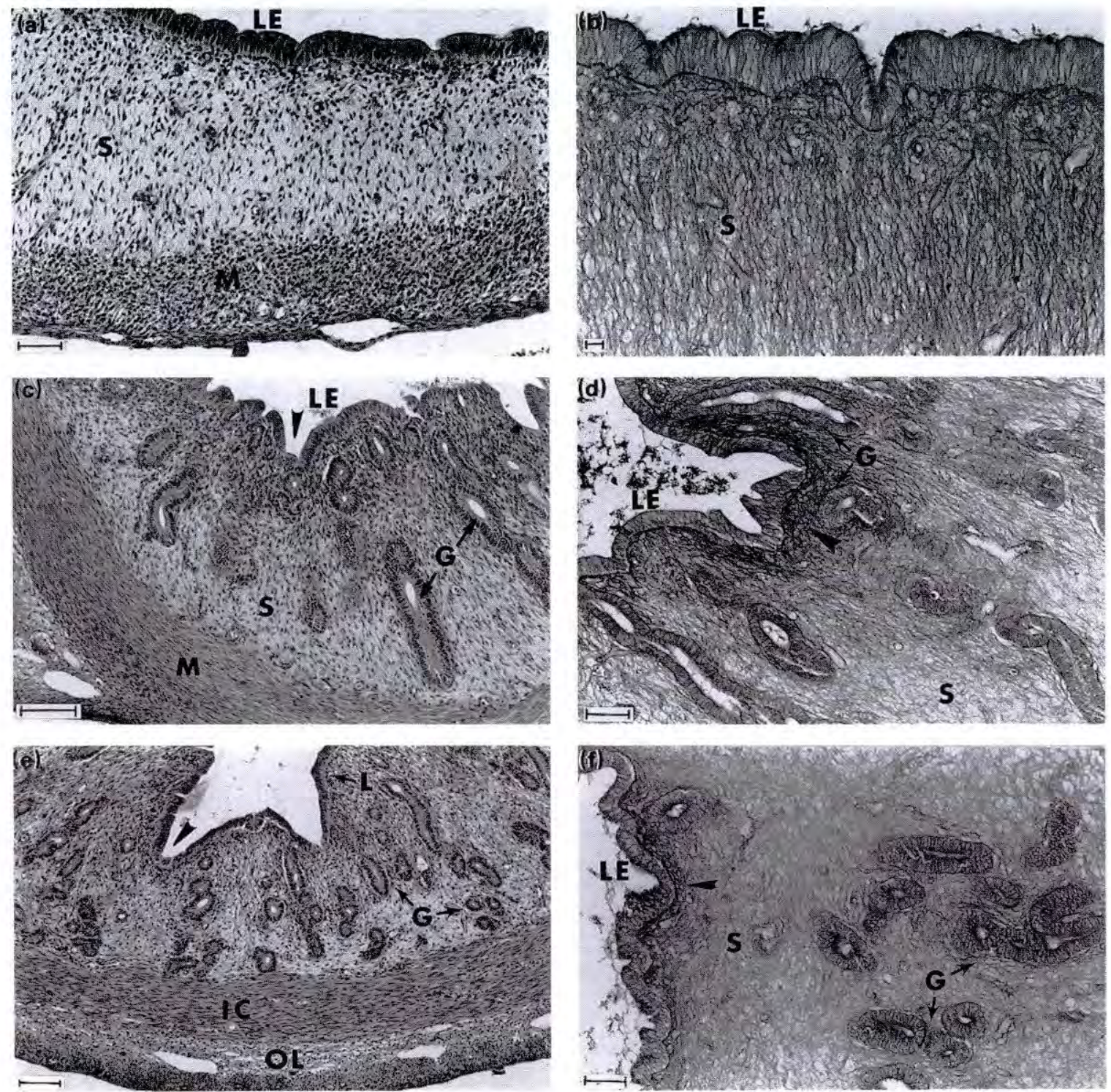

Fig. 2. Representative photomicrographs illustrating patterns of histogenesis and distribution of glycosaminoglycans (GAGs) in the developing neonatal porcine uterine wall (a) and (b) at birth (day 0 ) and (c) and (d) on day 28 and (e) and (f) on day 56. Sections were stained together with either Mayer's haematoxylin and eosin (a, c, e), or Alcian blue$8 \mathrm{GX}$ in the presence of $0.1 \mathrm{~mol} \mathrm{MgCl} \mathrm{1}^{-1}(\mathrm{~b}, \mathrm{~d}, \mathrm{f})$. Under these conditions, Alcian blue- $8 \mathrm{GX}$ binds to both sulfated and unsulfated GAGs. Day 0: (a) note the slightly corrugated appearance of luminal epithelium (LE), organization of endometrial stroma (S), and state of development of the myometrium (M). Endometrial glands are absent. (b) Staining with Alcian blue-8GX is homogeneous. Day 28: (c) note presence of endometrial folds (arrowhead), glands (G) penetrating endometrial stroma (S), and development of the myometrium (M). (d) Note distinct zone of alcianophilia (arrowhead) in shallow stroma immediately beneath luminal epithelium (LE) and adjacent to the necks of developing uterine glands (G). Day 56: (e) endometrial folds (arrowhead) are well developed. Coiled, branched uterine glands $(\mathrm{G})$ extend from the luminal surface $(\mathrm{L})$ to the myometrium. Both inner circular (IC) and outer longitudinal (OL) myometrial smooth muscle layers are apparent and well developed. (f) Alcianophilia persists (arrowhead) in shallow stroma (S) immediately beneath luminal epithelium (LE). Uterine glands $(G)$ are indicated. Scale bar (a) (d) (f) $=50 \mu \mathrm{m} ;(\mathrm{b})=10 \mu \mathrm{m}$; (c) (e) $=100 \mu \mathrm{m}$.. 
indicate that early postnatal remodelling of the uterine wall occurs in an autonomous, developmentally programmed, steroid-independent manner (Ogasawara et al., 1983; Bigsby and Cunha, 1985). However, endocrine signals necessary to initiate or facilitate early postnatal uterine developmental events may be generated at birth. Bartol et al. (1988a) demonstrated that endometrial gland development could be inhibited by chronic administration of a progestin to ovariectomized newborn lambs, and later could be allowed to proceed by removal of this artificial progestin block. Onset of uterine gland development in the neonate may, therefore, involve negative control. In this case, birth and the consequent removal of uterine tissues from a potentially inhibitory prenatal endocrine environment may provide a permissive signal(s) necessary to ensure normal postnatal uterine development. It remains to be determined whether such perinatal endocrine mechanisms affect development of the pig uterus.

\section{Cellular and Molecular Characteristics of Neonatal Uterine Development}

In a series of studies, Spencer et al. (1992b, 1993a) used uteri obtained by hysterectomy of crossbred neonatal pigs on day $0,7,14,28,42$ and 56 to establish relationships between morphogenetic, cellular and molecular events characteristic of endometrial development during the period of postnatal life when ovarian factors are not essential for support of uterine growth and histogenesis. Autoradiography of uterine tissues, labelled in vitro with $\left[\right.$ methyl- $\left.{ }^{3} \mathrm{H}\right]$ thymidine $\left(\left[{ }^{3} \mathrm{H}\right] \mathrm{Thd}\right)$, revealed that transformation of the endometrium from an infantile, glandless state at birth, to a more nearly mature histoarchitectural state with onset of gland development, involved both age- and tissue site-specific changes in patterns of DNA synthesis (Spencer et al., 1993a). $\left[{ }^{3} \mathrm{H}\right] \mathrm{T}$ hd labelling indices (LI) for both luminal epithelium and endometrial stroma were maximal at birth and decreased thereafter, although the decline in stromal $\left[{ }^{3} \mathrm{H}\right] \mathrm{Thd}$ LI was more gradual (Fig. 3). In contrast, glandular epithelial $\left[{ }^{3} \mathrm{H}\right] \mathrm{Thd}$ LI increased abruptly after birth and was maximal on days 7 and 14 . Intense $\left[{ }^{3} \mathrm{H}\right]$ Thd labelling was seen in association with epithelial cells in the tips and deeper lateral borders of developing endometrial glands (Fig. 4). Glandular epithelial $\left.{ }^{3} \mathrm{H}\right] \mathrm{Thd}$ LI increased in deeper endometrial zones with increasing age as glands grew into these regions of the uterine wall. Thus, as reported for neonatal sheep (Bartol et al., 1988a) and mice (Ogasawara et al., 1983; Bigsby and Cunha, 1985), pronounced, spatially focused increases in the proportion of epithelial cells actively synthesizing DNA and a more gradual decrease in stromal DNA synthesis were shown to accompany the appearance and proliferation of uterine glands in neonatal pigs.

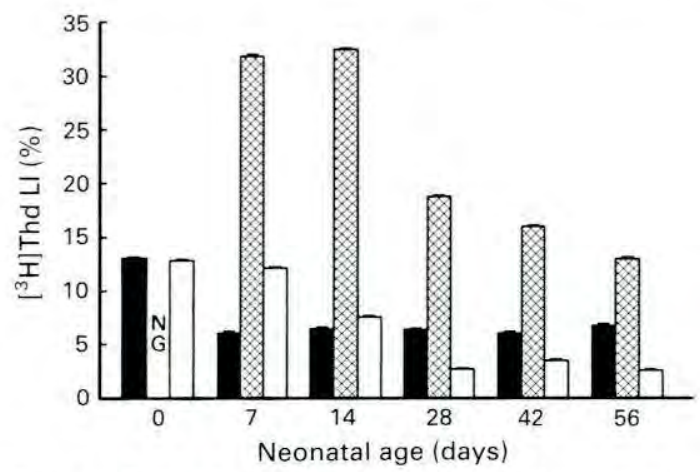

Fig. 3. Effects of neonatal age from birth (day 0 ) to day 56 on porcine endometrial [methyl- ${ }^{3} \mathrm{H}$ ] thymidine ( $\left[{ }^{3} \mathrm{H}\right] \mathrm{Thd}$ ) labelling index (LI) for ( $)$ luminal epithelium, ( glandular epithelium and $(\square)$ stroma. Luminal epithelial LI was maximal at birth, decreased $(P<0.01)$ to day 7 , and remained stable to day 56 . In contrast, glandular epithelial LI was maximal on days 7 and 14 (day $\times$ epithelial type $P<0.01$ ) and declined thereafter. Uterine glands are absent at birth (NG). Stromal LI declined $(P<0.01)$ after day 0 to minimum values after day 14. Adapted from Spencer et al. (1993a). 

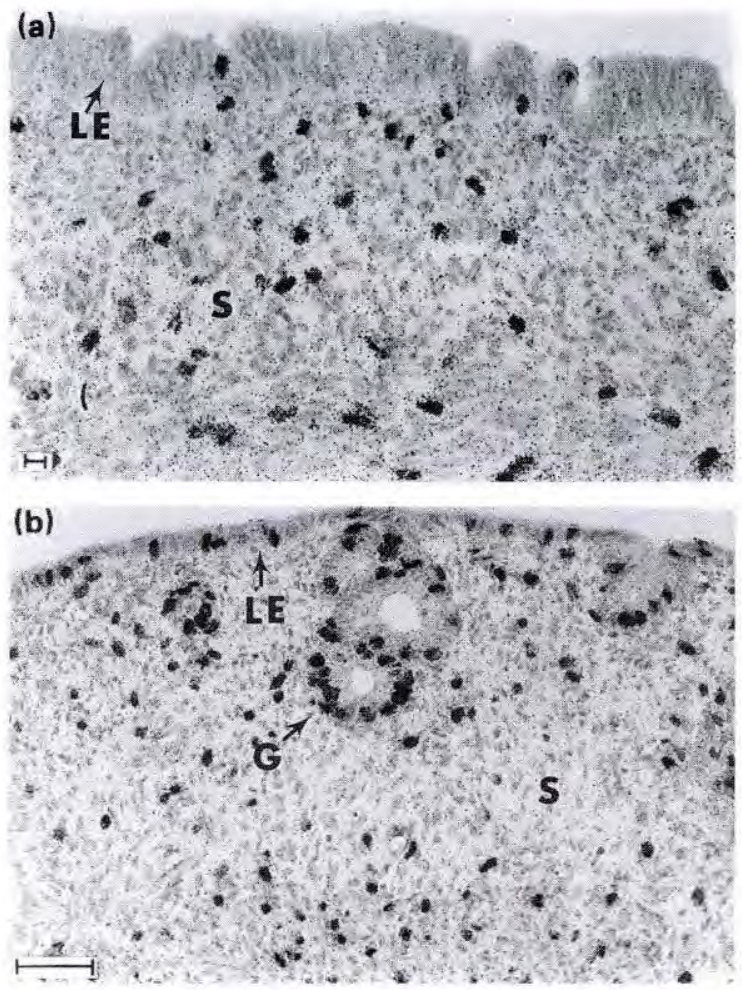

Fig. 4. Representative photomicrographs illustrating the distribution of autoradiographic grains in uterine tissue sections from neonatal pigs labelled in vitro with [methyl- $\left.{ }^{3} \mathrm{H}\right]$ thymidine $\left(\left[^{3} \mathrm{H}\right] \mathrm{Thd}\right)$. (a) Day $\mathrm{O}$ (birth): note distribution of nuclear labelling in luminal epithelium (LE) and stroma (S). (b) Day 14: note intense focal $\left[{ }^{3} \mathrm{H}\right]$-Thd labelling in nuclei of glandular (G) compared with luminal epithelium LE), and reduced labelling in stroma (S). Scale bars $(a)=10 \mu \mathrm{m}$; (b) $=50 \mu \mathrm{m}$.

The observation that progressive, synchronous development of endometrial glands in neonatal pigs involves ovary-independent, temporal and spatial regulation of epithelial DNA synthesis is consistent with the idea that this process is regulated locally. Such local regulation could be achieved via mechanisms that support the establishment of unique, zonally variable tissue microenvironments (Padykula et al., 1984, 1989; Sugimura et al., 1986; Spencer et al., 1993a). Developmentally critical tissue microenvironments are likely to become established as a consequence of interactions between epithelium and underlying mesenchyme or stroma. Reciprocal interactions between these tissue compartments support both morphogenesis and differentiation of many tissues, including those of the uterus (Cunha and Lung, 1979, Cunha et al., 1983, 1989; Sanders, 1988; Sharpe and Ferguson, 1988; Bigsby, 1991). Studies of murine uterine tissues indicate that mesenchyme is required to direct and specify patterns of epithelial development, whereas epithelium is required to support or direct organization and differentiation of endometrial stroma as well as myometrial organization and growth (Cunha et al., 1983, 1989; Brody and Cunha, 1989a; Bigsby, 1991; Wegner and Carson, 1992). Dynamic reciprocal interactions of this kind provide a system for local control and coordination of developmentally important epithelial and stromal cell behaviours including proliferation, movement, adhesion and differentiation (Sharpe and Ferguson, 1988; Brody and Cunha, 1989a,b; Cunha et al., 1989; Wegner and Carson, 1992). Mechanisms through which permissive or inductive stimuli are communicated between epithelial and stromal compartments have not been precisely defined. However, spatially focused developmental events may not only reflect, 
but may also be coordinated by, alterations in the tissue microenvironment produced through independent and synergistic effects of components of the extracellular matrix (ECM) and diffusible morphogens (Flaumenhaft and Rifkin, 1991; Jackson et al., 1991; Ettinger and Doljanski, 1992; Schubert, 1992).

\section{The ECM, glycosaminoglycans and local control of uterine wall development}

Glycosaminoglycans (GAGs), including hyaluronic acid (HA), and the sulfated GAGs (SGAGs) chondroitin sulfate (CS, including dermatan sulfate), heparan sulfate (HS) and keratan sulfate, are negatively charged, complex carbohydrates that, with the exception of HA, are found as components of proteoglycans in the ECM (Jackson et al., 1991). Through their ability to affect cell behaviour directly and to mediate access of growth factors or other diffusible morphogens to target cells, GAGs can have profound effects on morphogenetic and cytodifferentiative events in developing tissues and organs (Cunha and Lung, 1979; Bernfield, 1981; Toole, 1991; Ettinger and Doljanski, 1992). Reciprocal interactions between cell compartments in developing epithelial-mesenchymal organs, such as the uterus, produce alterations in tissue GAG biochemistry that, in turn, affect cell behaviour in both compartments (Cunha and Lung, 1979; Hayashi et al., 1982; Bissell and Barcellos-Hoff, 1987; Ettinger and Doljanski, 1992). Thus, both cell-cell and cell-ECM interactions contribute to the establishment and evolution of dynamic physical and biochemical conditions in which local developmental events occur.

When neonatal pig uterine tissues obtained between birth and day 56 were stained with Alcian Blue-8GX $(A B)$, a distinct pattern of stromal GAG distribution was seen in clear temporal and spatial association with the appearance and proliferation of endometrial glands (Spencer et al., 1993a). A GAGrich alcianophilic zone, which was not present at birth, was observed in the shallow stroma of uteri from day 7 and later. Staining was most intense at the epithelial-mesenchymal interface and in stromal areas immediately adjacent to luminal epithelium and surrounding the necks of developing endometrial glands (Fig. 2). Staining characteristic of SGAGs persisted in those areas adjacent to epithelium where [ $\left.{ }^{3} \mathrm{H}\right] \mathrm{Thd}$ LI was minimal (Spencer et al., 1993a). Similar relationships were reported for the developing ovine uterus (Bartol et al., 1988a,b).

Autoradiography of D-[6- $\left.{ }^{3} \mathrm{H}\right]$ glucosamine- $\left.\left({ }^{3} \mathrm{H}\right] \mathrm{GlcN}\right)$-labelled pig uterine tissues obtained between birth and day 56 revealed significant incorporation of this GAG precursor into the stroma (Spencer et al., 1993a). Labelling with $\left[{ }^{3} \mathrm{H}\right] \mathrm{GlcN}$ was most intense in shallow, subepithelial stroma at birth and declined thereafter as zonal $\mathrm{AB}$ staining became apparent and glandular epithelial DNA synthesis increased (Fig. 5). Products of pig uterine $\left[{ }^{3} \mathrm{H}\right] \mathrm{GlcN}$ metabolism have yet to be identified in situ. However, neonatal uterine tissues can synthesize GAGs from $\left[{ }^{3} \mathrm{H}\right] \mathrm{GlcN}$ in vitro (Bartol et al., 1992; Wiley et al., 1992). When GAGs extracted from uterine tissues obtained on days 7, 14 and 49 were subjected to DEAE anion exchange chromatography as described by Bellin and Ax (1987), three major DEAE-positive peaks of $\left.{ }^{3} \mathrm{H}\right] \mathrm{GlcN}$-labelled material were identified. On the basis of the elution positions of these peaks relative to authentic GAG standards and the sensitivity of labelled material in individual peaks to digestion with Streptomyces hyaluronidase (EC 4.2.2.1), $\mathrm{HNO}_{2}$ and chondroitinase $\mathrm{ABC}$ (EC 4.2.2.4), it was determined that uterine tissues produced HA, HS and CS from $\left[{ }^{3} \mathrm{H}\right] \mathrm{GlcN}$ substrate (Fig. 6). Moreover, the proportion of newly synthesized GAG identified as SGAG (HS and CS) increased after day 7, whereas relative production of HA decreased (Bartol et al., 1992).

Data indicate that GAGs are actively synthesized by pig uterine tissues at birth and accumulate in endometrial stroma and at the epithelial-mesenchymal interfaces where an SGAG-rich zone is established and maintained beneath morphogenetically stable areas of uterine epithelium. Similar relationships have been reported for other developing epithelial-mesenchymal organs (Cunha and Lung, 1979; Bernfield, 1981; Hayashi et al., 1982; Silberstein and Daniel, 1982). Site-specific, epithelial-mesenchymal interactions may alter patterns of synthesis and deposition of GAGs and produce changes in local microenvironmental conditions that are necessary to facilitate epithelial mitotic activity and genesis of endometrial glands, as well as more subtle cytodifferentiative events associated with maturation of the uterine wall (Hayashi et al., 1982; Spooner and Thompson-Pletscher, 1986; Jackson et al., 1991; Spencer et al., 1993a). Direct interactions of GAGs with cell surface binding domains can affect cell proliferation, mRNA stability and patterns of protein synthesis, and may determine whether cells are competent to respond to growth factors (Bissell and Barcellos-Hoff, 1987; Jackson et al., 1991; Schubert, 1992; Kan et al., 


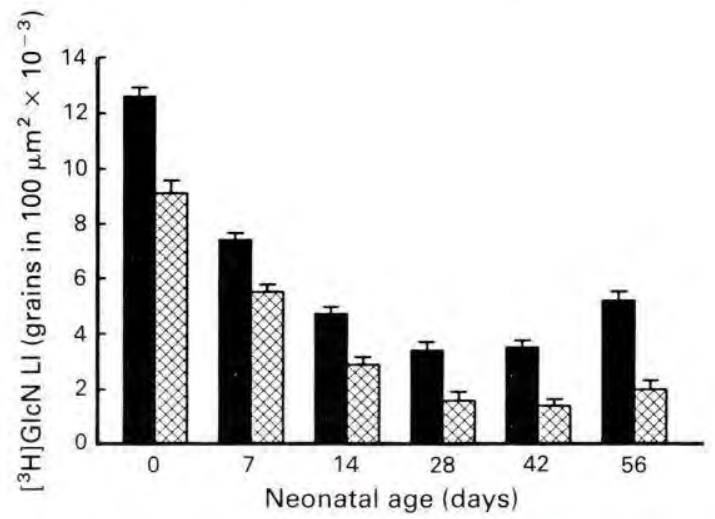

Fig. 5. Effects of neonatal age, from birth (day 0) to day 56 , on D-[6- $\left.{ }^{3} \mathrm{H}\right]$ glucosamine $\left(\left[{ }^{3} \mathrm{H}\right] \mathrm{GlcN}\right)$ labelling index (LI; grains in $100 \mu^{2} \times 10^{-3}$ ) for porcine endometrial stroma. LI was determined for ( shallow and ( deep stromal zones. Shallow stroma was defined to include that area extending $100 \mu \mathrm{m}(50 \mu \mathrm{m}$ in uteri from day 0$)$ from the basal aspect of the luminal epithelium. Deep stroma was defined as that area extending $100 \mu \mathrm{m}(50 \mu \mathrm{m}$ in uteri from day 0) adluminally from the interface of the inner circular layer of developing myometrium and the endometrial stroma. Overall, stromal $\left[{ }^{3} \mathrm{H}\right] \mathrm{GlcN}$ LI was greater for shallow than for deep stroma $(P<0.01)$, maximal in both zones at birth, and decreased curvilinearly to minimum values on days 28 and 42 (cubic effect of day. $P<0.01$ ). However, $\mathrm{LI}$ increased in shallow stroma from day 28 to day 56 (day $\times$ stromal zone, $P<0.03$ ). Uteri were obtained by hysterectomy of neonatal gilts on days $0(n=4), 7(n=5), 14(n=5) 28(n=3), 42(n=6)$ and $56(n=3)$. Adapted from Spencer et al. (1993a).

1993). When taken into cells, GAGs may affect second messenger systems by altering calcium dynamics, protein kinase activity and intranuclear events that determine whether cells can traverse the cell cycle (Jackson et al., 1991). Equally important, GAGs can bind polypeptide growth factors specifically and nonspecifically (Flaumenhaft and Rifkin, 1991). Consequently, diffusible growth factors or other morphogens may be (1) trapped or concentrated within ECM zones and prevented from gaining access to target cells, (2) protected from proteolytic degradation and presented directly to nearby target cells or cells that migrate into the factor-rich zone, or (3) released to act on target cells following ECM degradation (Flaumenhaft and Rifkin, 1991; Schubert, 1992). Thus, the ability of endometrial tissues to affect temporal and spatial alterations in the nature and distribution of GAGs may represent an important mechanism for local regulation and coordination of uterine morphogenetic and cytodifferentiative events.

Marker-coupled lectins have been used to identify specific carbohydrate residues that could mediate interactions of cells with other cells, the ECM, and growth factors during the course of development of many organs including the uterus (Bartol et al., 1988b; Aplin, 1991; Spencer et al., 1992b; Spicer and Schulte, 1992). A histochemical study of the distribution of endometrial lectin-binding sites in neonatal porcine uteri (Spencer et al., 1992b) revealed that binding patterns for three lectins, including ConA (specificity: $\alpha$-D-mannose and $\alpha$-D-glucose), RCA-I (specificity: $\beta$-D-galactose and $\beta$ - $N$-acetyl-Dgalactosamine), and UEA-I (specificity: $\alpha$-L-fucose) changed in an age-related manner between birth and day 56. Binding patterns observed for RCA-I were unique. Staining with this lectin was homogeneous for luminal epithelium but distinctly variegated for glandular epithelium (Fig. 7), indicating that there 


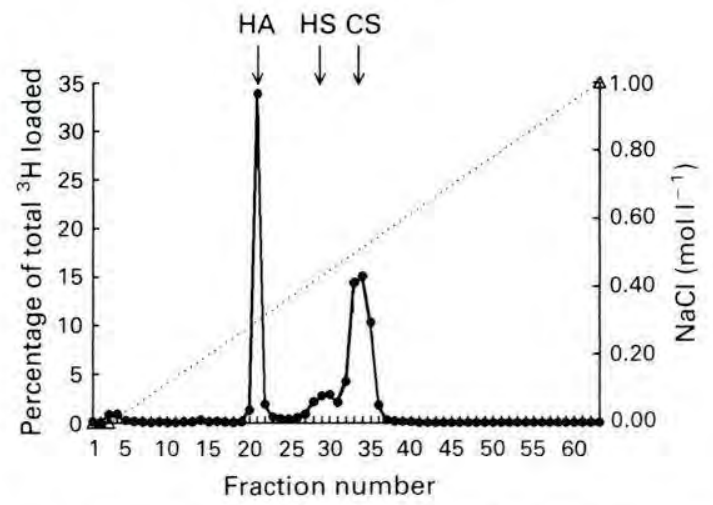

Fig. 6. Representative DEAE anion exchange chromatogram showing elution positions of major $\mathrm{D}-\left[6-{ }^{3} \mathrm{H}\right]$ glucosamine $\left(\left[{ }^{3} \mathrm{H}\right] \mathrm{GlcN}\right)$-labelled, lipid- and protein-free, potassium acetate precipitable glycosaminoglycans (GAGs) extracted from neonatal porcine uterine tissue obtained on postnatal day 49. Three major peaks of $\left[{ }^{3} \mathrm{H}\right] \mathrm{Gl} \mathrm{CN}$-labelled material were consistently identified when GAGs extracted from uterine tissues obtained on days 7, 14 or 49 were applied to an HPLC DEAE 5PW anion exchange column and eluted with a linear $\mathrm{NaCl}$ gradient $(. . .$.$) as described by Bellin$ and $A x$ (1986). On the basis of (I) the elution positions of these peaks relative to authentic GAG standards including hyaluronic acid (HA), heparan sulfate (HS), and chondroitin sulfate (CS), and (2) the sensitivity of labelled material in individual peaks to digestion with Streptomyces hyaluronidase ( $\mathrm{EC}$ 4.2.2.1), $\mathrm{HNO}_{2}$ and chondroitinase $\mathrm{ABC}$ (EC 4.2.2.4), uterine tissues were determined to produce $H A$, $\mathrm{HS}$ and $\mathrm{CS}$ from $\left[{ }^{3} \mathrm{H}\right] \mathrm{GlcN}$ substrate. Data are presented as a percentage of total ${ }^{3} \mathrm{H}$-labelled material loaded on to the column.

are alterations in the distribution or orientation of $\beta$-D-galactose and (or) $\beta$ - $N$-acetyl-D-galactosamine residues associated with these cells. Phenotypic variations of this kind may reflect altered production of glycosidases and glycosyltransferases, or changes in the structure of core proteins to which carbohydrates attach (Spicer and Schulte, 1992). These data provide additional evidence that local conditions support spatially unique development of specific endometrial cell populations.

\section{Neonatal uterine proteins}

When proteins produced from radiolabelled amino acid substrate by tissues maintained in organotypic culture are separated by two-dimensional PAGE and visualized fluorographically, the result is a twodimensional PAGE 'fingerprint' that defines the functional characteristics or state of differentiation of that tissue (Cunha et al., 1983). These procedures have been used to identify molecular markers of normal and aberrant murine urogenital tract development (Carter et al., 1982; Newbold et al., 1984; Maier et al., 1985) and were applied recently in studies of the developing pig uterus (Bartol et al., 1991; Christenson et al., 1992; Vallet et al., 1992; Spencer et al., 1993b). Attention has been focused on the array of proteins produced by porcine neonatal uterine tissues from $\mathrm{L}-4-5-\left[{ }^{3} \mathrm{H}\right]$ leucine $\left(\left[{ }^{3} \mathrm{H}\right] \mathrm{Leu}\right)$ and released into explant medium. This set of proteins and polypeptides is likely to represent the array of uterine secretory products with potential for extracellular diffusion and, therefore, may include locally produced morphogens that affect the developmental behaviour of constituent cell populations. Proteins and polypeptide growth factors from the uterus have been implicated in mechanisms regulating adult ovine (Ikeda and Sirbasku, 


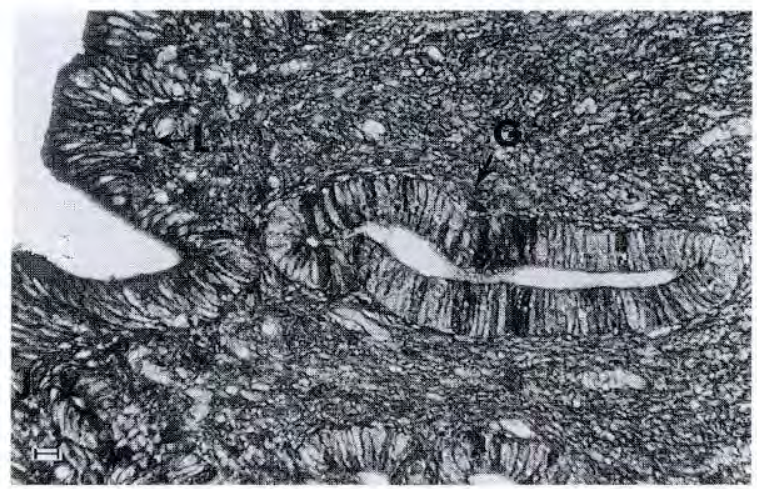

Fig. 7. Representative photomicrograph of the neonatal porcine uterine wall in cross-section illustrating the distribution of endometrial lectin binding sites (dark areas) for RCA-I (carbohydrate specificity: $\beta$-D-galactose and $\beta$ - $n$ acetyl-D-galactosamine). Note distinct variegated staining pattern in glandular $(\mathrm{G})$ as compared to luminal (L) epithelium. Example from neonatal day 14. Scale bar $=10 \mu \mathrm{m}$.

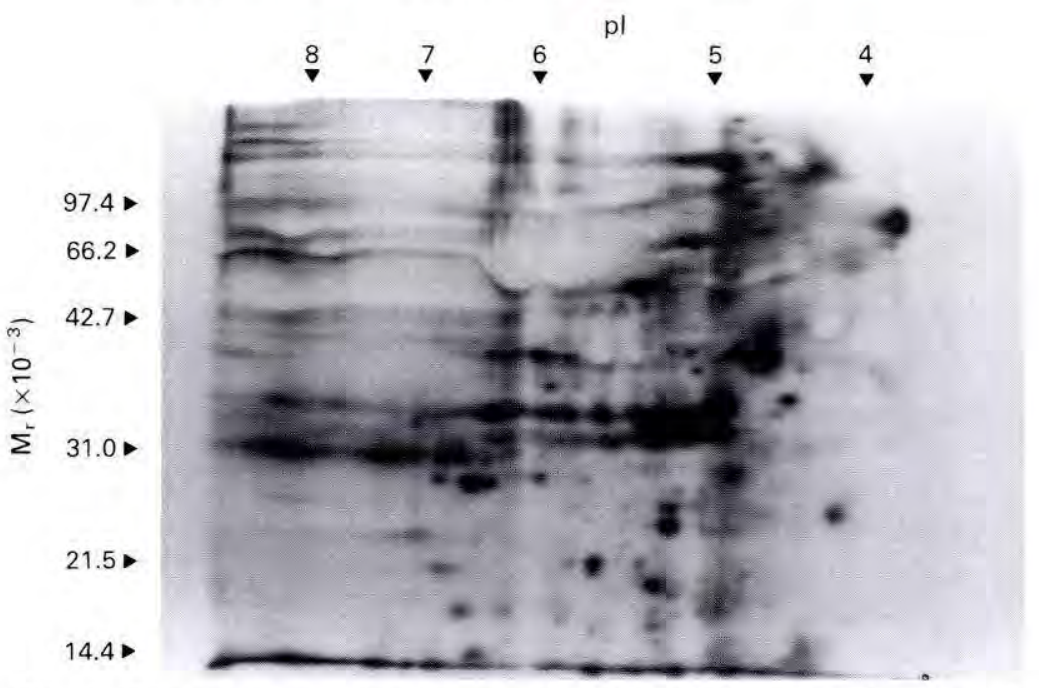

Fig. 8. Fluorograph of a two-dimensional PAGE gel illustrating the array of proteins and polypeptides produced from $\left[{ }^{3} \mathrm{H}\right]$ leucine and released into explant medium by neonatal porcine uterine tissue obtained on day 14 . Proteins were separated by isoelectric point (pI) in the first dimension and by molecular weight $\left(\mathrm{M}_{\mathrm{r}} \times 10^{-3}\right)$ in the second dimension using SDS-PAGE $(12.5 \%$ total acrylamide monomer).

1984; Bird et al., 1988; Reynolds et al., 1990) and porcine (Brigstock et al., 1989; Simmen et al., 1988, 1989 b) uterine growth and function.

Tissues obtained from neonatal gilts during the ovary-independent period of uterine growth produce complex arrays of proteins from $\left[{ }^{3} \mathrm{H}\right] \mathrm{Leu}$ (Fig. 8) that reflect the age and (or) histoarchitectural state of the uterine wall (Bartol et al., 1991; Christenson et al., 1992; Vallet et al., 1992; Spencer et al., 1993b). Consistent with observations of the effects of ovariectomy at birth on uterine growth and histogenesis mentioned above, preliminary observations suggest that patterns of uterine protein secretion do not differ between intact and ovariectomized gilts before neonatal day 60 (F. Bartol, A. Wiley and J. McGee, 
unpublished observations). Thus, both uterine morphogenetic and cytodifferentiative events characteristic of this period appear to proceed in an ovary-independent manner.

In a comparative study of uterine morphogenesis and protein secretion in hyperprolific Meishan $(n=22)$ and White crossbred $\left(\frac{1}{4}\right.$ each Chester White, Landrace, Large White and Yorkshire) gilts $(n=35)$, uteri were obtained at necropsy on day $1,14,28,42$ or 56 (birth $=$ day 0). Uterine weights were similar and increased in both breeds from day 1 to day 42 , but differed on day 56 (day $\times$ breed, $P<0.01)$ when ovarian $(0.2 \pm 0.1$ versus $1.4 \pm 0.1 \mathrm{~g})$ and uterine $(3.9 \pm 0.2$ versus $8.4 \pm 0.2 \mathrm{~g})$ weights were greater and endometrial gland development was advanced in Meishan gilts (Christenson et al., 1992). Marked uterine growth and development occurred in both Meishan and crossbred gilts between day 1 and day 42 , before differences in ovarian weights were observed. Uterine secretion of at least three $\left[{ }^{3} \mathrm{H}\right]$ Leu-labelled proteins $\left(\sim M_{\mathrm{r}} \times 10^{-3} / \mathrm{pI}: 45 / 6.0,25 / 6.2,20 / 5.5\right)$ increased in clear temporal association with uterine gland development during this period in both breeds. However, secretion of a fourth protein $\left(\sim M_{\mathrm{r}} \times 10^{-3} / \mathrm{pI}: 97 / 4.0\right)$ increased by day 28 in Meishan gilts only, and a fifth $\left(\sim M_{\mathrm{r}} / \mathrm{pI}\right.$ : 13/6.0) increased by day 56 in crossbred gilts only. General mechanisms regulating uterine development are likely to be highly conserved (Cunha et al., 1983). However, identification of breed-specific differences in patterns of neonatal uterine protein secretion between hyperprolific Meishan and White crossbred gilts provides indirect support for the idea that developmental events may affect adult uterine capacity.

Local morphoregulatory roles for individual proteins produced by neonatal uterine tissues remain to be defined. However, Vallet et al. (1992) demonstrated that one of these proteins ( $\left.\sim M_{\mathrm{r}} \times 10^{-3} / \mathrm{pI}: 20 / 5.5\right)$ is physically and immunochemically related to retinol-binding protein (RBP) produced by the endometrium of adult pigs (Adams et al., 1981; Trout et al., 1992). When $\left[{ }^{3} \mathrm{H}\right] \mathrm{Leu}-$ supplemented medium conditioned with neonatal porcine uterine tissues from day $0,3,6,9$ or 12 was subjected to quantitative immunoprecipitation with anti-human RBP antiserum (Dako, Carpinteria, CA) and precipitated material was subjected to SDS-PAGE, fluorography revealed two immunoreactive protein bands $\left(\sim M_{r} \times 10^{-3}: 19\right.$ and 20$)$. Densitometric analyses indicated that secretion of the major $20000 M_{\mathrm{r}}$ product increased from birth to day 3 and remained stable until day 12 , while secretion of the minor $19000 M_{\mathrm{r}}$ product decreased after day 6 (Vallet et al., 1992 and unpublished observations). Thus, uterine secretion of an immunoreactive RBP-like protein increases in association with the appearance and proliferation of endometrial glands and progressive development of the myometrium. Given the importance of retinoids as morphogens and in mediation of epithelial-mesenchymal interactions and epithelial maturation (Wedden, 1987; De Luca, 1991), increased production of RBP may be necessary to ensure that retinol dynamics are adequately regulated in the developing uterine wall. However, structural and functional similarities between RBP and chick purpurin - a neural cell adhesion-mediating protein that has $50 \%$ amino acid sequence homology with human RBP (Pervaiz and Brew, 1987) and displays retinolbinding activity (Schubert and LaCorbiere, 1986) - suggest that RBP could also act directly to promote cell-cell or cell-substratum interactions associated with uterine remodelling. Since adhesion-promoting properties of such molecules are affected by specific GAGs (Jackson et al., 1991), the role, if any, of RBP in mediation of uterine wall development may change in association with alterations in the quality of the ECM.

\section{Consequences in the Adult of Interruption of Uterine Development}

A method for interruption of the normal programme of uterine development is needed in order to test the hypothesis that uterine organizational events must proceed without interruption to ensure adult uterine competence. The idea that interruption of development during specific 'critical' periods could have lasting effects on tissue form and function is not new (Stockard, 1921). Accordingly, exposure of fetal and neonatal rodents to oestrogens or related xenobiotics was shown to reduce fertility and to produce a variety of structural and functional lesions in adult uterine tissues, including cystic endometrial hyperplasia, squamous metaplasia, adenomyosis, myometrial hypoplasia, reduced concentrations of oestrogen and progesterone receptors, altered steroid metabolism and responsiveness, and altered protein synthesis (Newbold et al., 1984; Branham et al., 1985a,b, 1988a,b,c; Forsberg, 1988; Medlock et al., 1988; Mori and Iguchi, 1988; Halling and Forsberg, 1990). It therefore seems reasonable to propose that oestrogen might be a useful tool with which to interrupt uterine development in neonatal pigs. 
Studies were conducted to determine effects of oestradiol valerate $\left(50 \mu \mathrm{g} \mathrm{kg}^{-1}\right.$ bodyweight day ${ }^{-1}$, i.m.), administered during specific periods of neonatal life associated with ovary-independent uterine development, on patterns of uterine growth, histogenesis and protein secretion (Spencer et al., 1993b). GAG synthesis (Bartol et al., 1992), and steady-state concentrations of insulin-like growth factor I (IGF-I) mRNA (Spencer et al., 1992a). For these studies, crossbred gilts ( 3 to 5 per group) received either corn oil vehicle or oestradiol valerate for seven consecutive days from either birth to day 6, day 7 to day 13 , or day 42 to day 48 , before hysterectomy on day 7,14 or 49 , respectively. Treatment intervals were chosen to coincide with infantile ( $<$ day 7), proliferative (days 7-14), and growth ( $>$ day 14) periods of endometrial development that were defined on the basis of gross, histological and biochemical characteristics of the developing uterine wall described above and elsewhere (Spencer et al., 1992b. 1993a,b).

The possibility that IGF-I is involved in normal porcine uterine development, or in mediation of uterine responses to oestrogen, is significant. IGF-I production is regulated developmentally in many tissues (D'Ercole et al., 1984; Lund et al., 1986; Simmen et al., 1989a). This growth factor is mitogenic for a number of cell types (Zapf and Froesch, 1986), including porcine endometrial cells (Simmen et al., 1989a) promotes cellular differentiation (Simmen et al, 1989a), and stimulates incorporation of sulfate into GAGs (Adashi et al., 1986). Although not established for the neonate, IGF-I receptors are present in (Hofig et al., 1991), and IGF binding proteins are produced by (Simmen and Simmen, 1990; Simmen et al., 1991) the adult pig uterus. In the immature and adult rat and pig, oestrogen-induced uterine growth and differentiation are accompanied by increased uterine production of IGF-I (Murphy and Ghahary 1990; Simmen et al., 1990; Carlsson and Billig, 1991). Thus, IGF-1 could be an autocrine or paracrine mediator of oestrogen action. In pigs (Lee et al., 1991) and other species (Daughaday and Rotwein, 1989), circulating concentrations of IGF-I increase postnatally in association with maturation of the somatotrophic axis. Consequently, IGF-l may also act in an endocrine fashion to influence uterine development in the neonate.

Table 1. Effects of oestradiol valerate, administered to neonatal gilts during infantile (days 0-6). proliferative (days 7-13) or growth (days 42-48) periods, on uterine wet weight, endometrial thickness, and myometrial thickness on neonatal days 7, 14 and 49

\begin{tabular}{|c|c|c|c|c|c|c|}
\hline \multirow[b]{2}{*}{ Day } & \multicolumn{2}{|c|}{$\begin{array}{l}\text { Uterine wet weight } \\
\text { (g) }\end{array}$} & \multicolumn{2}{|c|}{$\begin{array}{l}\text { Endometrial thickness } \\
\qquad(\mu \mathrm{m})\end{array}$} & \multicolumn{2}{|c|}{$\begin{array}{l}\text { Myometrial thickness } \\
\qquad(\mu \mathrm{m})\end{array}$} \\
\hline & $\mathrm{CO}^{\mathrm{b}}$ & $\mathrm{EV}^{\mathrm{c}}$ & $\mathrm{CO}$ & EV & $\mathrm{CO}$ & EV \\
\hline 7 & $1.1 \pm 0.3^{2}$ & $2.8 \pm 0.3^{*}$ & $282 \pm 59^{4}$ & $412 \pm 49^{*}$ & $222 \pm 19^{4}$ & $252 \pm 18$ \\
\hline 14 & $1.0 \pm 0.3^{4}$ & $3.2 \pm 0.3^{*}$ & $281 \pm 49^{\prime}$ & $525 \pm 42^{*}$ & $204 \pm 18^{2}$ & $221 \pm 16$ \\
\hline 49 & $9.8 \pm 2.0^{b}$ & $41.5 \pm 2.0^{*}$ & $815 \pm 49^{b}$ & $1535 \pm 43^{\circ}$ & $321 \pm 18^{b}$ & $911 \pm 16^{*}$ \\
\hline
\end{tabular}

-Neonatal gilts $(n=22)$ were treated with either oestradiol valerate $\left(\mathrm{EV}, 50 \mu \mathrm{g} \mathrm{kg}^{-1}\right.$ body weight day $\left.{ }^{-1}\right)$ or com oil vehicle $(\mathrm{CO})$ daily for 7 days before hysterectomy on either day $7(n: \mathrm{CO}=3$, EV $=4)$, I4 ( $n: \mathrm{CO}=3$, EV $=$ $5)$ or $49(n: \mathrm{CO}=3$, EV = 4). Adapted from Spencer et al. (1993b).

'For $\mathrm{CO}$ data, values in the same column with different superscripts are significantly different $(P<0.01)$.

Within each day, significant $(P<0.01)$ effects of oestradiol valerate are denoted by $\left({ }^{\circ}\right)$. Day $\times$ treatment interactions $(P<0.01)$ were detected for all responses.

Treatment of neonatal gilts with oestradiol valerate increased uterine wet weight and endometrial thickness in all periods, while myometrial thickness increased following treatment during the growth period only (Table 1). Histologically, uteri of all gilts treated with oestradiol valerate displayed precocious development of endometrial glands and folds (Spencer et al., 1993b). Both gross and histological responses to oestradiol valerate were most pronounced following treatment during the growth period. Measurement of radioactivity associated with $25\left[{ }^{3} \mathrm{H}\right]$ Leu-labelled uterine proteins identified by twodimensional PAGE revealed that treatment with oestradiol valerate during infantile, proliferative and growth periods affected production of three, eight, and 14 individual proteins, respectively (Spencer et al., 
1993b). Overall, oestradiol valerate decreased the percentage of total [ $\left.{ }^{3} \mathrm{H}\right] \mathrm{GlcN}$-labelled uterine GAG identified by HPLC DEAE anion exchange chromatography as HA (control versus oestradiol valerate treated: $62.3 \%>51.5 \%$, SEM $=1.2, P<0.01$ ) and increased that identified as SGAG (Bartol et al., 1992), including HS $(12.9 \%<15.0 \%$, SEM $=0.5, P<0.05)$, and CS $(24.8 \%<33.6 \%$, SEM $=1.3 \%, P<0.01)$. Northern hybridization analysis of poly $(A)^{+}$RNA isolated from neonatal uteri obtained from both control and oestradiol valerate-treated gilts using porcine IGF-I cDNA probe Sigf.3 (Tavakkol et al., 1988) revealed a single $1.2 \mathrm{~kb}$ transcript. Consistent with observations reported for the neonatal rat (Carlsson and Billig, 1991), steady-state concentrations of pig uterine IGF-I mRNA decreased $(P<0.01)$ after day 7 (relative absorbance units for days 7, 14 and 49: 7.8, 4.7 and 5.2; SEM =0.4). However, treatment with oestradiol valerate increased $(P<0.01$ ) uterine IGF-I mRNA levels by 1.4 times compared with controls. In addition, peripheral plasma concentrations of IGF-I increased $(P<0.01)$ linearly with age from day 7 to day 49 (means for days 7,14 and $49: 28.6,34.3$ and $50.4 \mathrm{ng} \mathrm{m}^{-1}$; SEM $=2.3$ ) and following treatment with oestradiol valerate $(P<0.02)$, regardless of when exposure occurred (control versus oestradiol valerate treated: $37.8<51.1 \mathrm{ng} \mathrm{ml}^{-1}$, SEM $=3.8$; Spencer et al., 1992a).

These studies demonstrated clearly that oestradiol valerate can be used to disrupt the normal programme of physical, biochemical and endocrine events associated with development of the pig uterine wall. Responses of the neonatal uterus to oestradiol valerate can be interpreted to indicate that (1) uterine tissues are sensitive to oestrogen, (2) acquisition of oestrogen sensitivity occurs progressively in the developing uterine wall, as reported for other species (Katzenellenbogen, 1979; Kaye, 1983; Pasqualini and Sumida, 1986), and (3) oestrogen-sensitive pig uterine cell populations develop first in the endometrium (Spencer et al., 1993b). In addition, effects of oestradiol valerate on uterine growth, histoarchitecture and patterns of protein secretion are unique to the periods when oestrogen exposure occurs (Spencer et al., 1993b). Such period-specific responses may reflect (1) the size and nature of uterine cell populations competent to respond to oestrogen, or soluble mediators of oestrogen action such as IGF-I, and (2) the consequences of oestrogen-induced aberrations in epithelial:mesenchymal ratio and related changes in patterns of cell-cell and cell-ECM interactions, through which both tissue form and function are likely to be determined (Bissell and BarcellosHoff, 1987; Ettinger and Doljanski, 1992; Spencer et al., 1993b). As the ability of uterine cells to respond to xenobiotic or natural organizational signals can change with time, and may also be determined by physicochemical relationships that exist or develop between cells or betweeen cells and their associated ECM, even subtle alterations in local microenvironmental conditions may have profound effects on the developmental fate of uterine tissues (Taguchi et al., 1988; Ettinger and Doljanski, 1992).

Recently, a study was conducted to determine whether oestradiol valerate-induced internuption of uterine development during the first two weeks of neonatal life, the period when effects of oestradiol valerate on uterine histoarchitecture were confined to the endometrium (Spencer et al., 1993b), would affect reproductive performance in adult pigs. Gilts treated with either oestradiol valerate $\left(50 \mu \mathrm{g} \mathrm{kg}^{-1}\right.$ body weight day ${ }^{-1}$, i.m.; $n=8$ ) or corn oil $(n=9)$ daily, from birth to day 13, were allowed to reach puberty and were mated naturally at their second oestrus. Treatment did not affect the ability of adults to cycle or conceive, and did not affect ovulation rate as reflected by the number of corpora lutea ( $16 \pm 0.5$ ) identified on the ovaries of oestradiol valerate- and corn oil-treated gilts at necropsy on day 45 of gestation. However, neonatal oestradiol valerate treatment reduced $(P<0.08)$ the number of potentially viable conceptuses per gilt (oestradiol valerate $=8.9<$ corn oil $\times 11.8$, SEM $=1.0$ ), and increased $(P<0.01)$ the percentage of total conceptuses identified as necrotic or deformed (oestradiol valerate $=17.1>$ corn oil $=1.0$, SEM $=3.5 \%$ ). The proportion of animals with necrotic conceptuses was 1 of 9 for control gilts, in which a single necrotic conceptus was found, and 7 of 8 for oestradiol valerate treated gilts, in which 11 necrotic conceptuses and two grossly malformed fetuses were identified. Embryonic survival, expressed as the proportion of corpora lutea, represented by viable conceptuses on gestational day 45 , was reduced $(P<0.05)$ by $22 \%$ in neonatally oestradiol valeratetreated gilts (oestradiol valerate $=54.5<$ control $=76.9$, SEM $=6.9 \%$ ).

\section{Conclusion}

Data indicate that events sensitive to oestradiol valerate-induced perturbation during the first two weeks of neonatal life may be required to proceed without interruption to ensure that adult porcine uterine 
capacity is not compromised. More generally, results support the hypothesis that the ability of adult uterine tissues to recognize and integrate signals necessary for establishment and maintenance of pregnancy in pigs (Bazer, 1992) may be determined, in part, by the degree of success realized during critical periods of uterine development.

Data reviewed herein suggest that critical uterine developmental events may be regulated locally, through dynamic, reciprocal, cell-cell and cell-ECM interactions, and underscore the importance of efforts to delineate these mechanisms. To this end, use of oestrogens or other natural or xenobiotic agents as tools with which to manipulate uterine developmental events and induce definable lesions in adult uterine tissues may provide strategies for identification of both developmental and functional determinants of uterine capacity in pigs.

The authors thank F. W. Bazer (Texas A\&M University) and R. C. M. Simmen (University of Florida) for valuable discussions and technical collaboration that have contributed significantly to development of this research.

This work was supported in part by USDA-NRICGP Grant No. 91-37203-6605 to FF Bartol. This manuscript represents contribution No. 4-933501 of the Alabama Agricultural Experiment Station. Mention of names is necessary to report factually on available data; however, the USDA neither guarantees nor warrants the standard of the product, and use of the name by USDA implies no approval of the product to the exclusion of others that may also be suitable.

\section{References}

Adams KL, Bazer FW and Roberts RM (1981) Progesteroneinduced secretion of a retinol-binding protein in the pig uterus Joumal of Reproduction and Fertility 62 39-47

Adashi EY, Resnick CE, Svoboda ME, Van Wyk JJ, Hascall VC and Yanagishita $M$ (1986) Independent and synergistic actions of somatomedin- $C$ in the stimulation of proteoglycan biosynthesis by cultured rat granulosa cells Endocrinology $118456-458$

Aplin JD (1991) Glycans as biochemical markers of human endometrial secretory differentiation joumal of Reproduction and Ferilitity 92 525-541

Atchley WR. Logsdon T and Cowley DE (1991) Uterine effects, epigenetics, and postnatal skeletal development in the mouse Evolution 45 891-909

Atkinson BA, King GJ and Amoroso EC (1984) Development of the caruncular and intercaruncular regions in the bovine endometrium Biology of Reproduction 30 763-774

Bal HS and Getty R (1970) Postnatal growth of the swine uterus from birth to six months Growth 34 15-30

Bartol FF, Wiley AA, Coleman DA, Wolfe DF and Riddell MC (1988a) Ovine uterine morphogenesis: effects of age and progestin administration and withdrawal on neonatal endometrial development and DNA synthesis joumal of Animal Science 66 3000-3009

Bartol FF, Wiley AA and Goodlet DR (1988b) Ovine uterine morphogenesis: histochemical aspects of endometrial development in the fetus and neonate Joumal of Animal Science 66 1303-1313

Bartol FF, Spencer TE, Wiley AA and Coleman DA (1991) Effects of neonatal age on porcine uterine protein synthesis Joumal of Animal Science 69 (Supplement 1) 419-420

Bartol FF, Wiley AA, Spencer TE and Coleman DA (1992) Neonatal porcine uterine glycosaminoglycan synthesis is affected by age and estrogen administration Biology of Reproduction 46 (Supplement 1) 172

Bazer FW (1992) Mediators of maternal recognition of pregnancy in mammals Proceeding of the Society of Experimental Biology and Medicine 199 373-384

Bazer FW, Thatcher WW, Martinat-Botte $F$ and Terqui $\mathbf{M}$ (1988) Sexual maturation and morphological development of the reproductive tract in Large White and prolific Chinese Meishan pigs Joumal of Reproduction and Fertility 83 723-728

Bellin ME and Ax RL (1987) Purification of glycosaminoglycans from bovine follicular fluid Joumal of Dainy Science $\mathbf{7 0}$ 1913-1919

Bernfield MR (1981) Organization and remodeling of the extracellular matrix in morphogenesis. In Morphogenesis and Pattern Fonnation pp 139-162 Ed. TC Connelly. Raven Press, New York

Bigsby RM (1991) Reciprocal tissue interactions in morphogenesis and hormonal responsiveness of the female reproductive tract. In Cellular Signals Controlling Uterine Function pp 11-20 Ed. LA Lavia. Plenum Press, New York

Bigsby RM and Cunha GR (1985) Effects of progestins and glucocorticoids on deoxyribonucleic acid synthesis in the uterus of the neonatal mouse Endocrinology $1172520-2526$

Bird RC, Bartol FF, Daron H. Stringfellow DA and Riddell MG (1988) Mitogenic activity in ovine uterine fluids: characterization of a growth factor activity which specifically stimulates myoblast proliferation Biochemical and Biophysical Research Communications 156 108-115

Bissell MJ and Barcellos-Hoff MH (1987) The influence of extracellular matrix on gene expression. Is structure the message? Joumal of Cell Science 8 (Supplement 8) 327-343

Branham WS, Sheehan DM, Zehr DR, Medock KL, Nelson CJ and Ridlon E (1985a) Inhibition of rat uterine gland genesis by tamoxifen Endocrinology 117 2238-2248

Branham WS, Sheehan DM. Zehr DR, Ridlon E and Nelson CJ (1985b) The postnatal ontogeny of rat uterine glands and age-related effects of $17 \beta$-estradiol Endocrinology 117 2229-2237

Branham WS, Zehr DR, Chen J and Sheehan DM (1988a) Postnatal uterine development in the rat: estrogen and antiestrogen effects on luminal epithelium Teratology 38 29-36

Branham WS, Zehr DR, Chen JJ and Sheehan DM (1988b) Alterations in developing rat uterine cell populations after neonatal exposure to estrogens and antiestrogens Teratology $38271-279$ 
Branham WS, Zehr DR, Chen JJ and Sheehan DM (1988c) Uterine abnormalities in rats exposed neonatally to diethylstilbestrol, ethynylestradiol, or clomiphene citrate Toxicology 51 201-212

Brigstock DR, Heap RB and Brown KD (1989) Polypeptide growth factors in uterine tissues and secretions joumal of Reproduction and Fertility 85 747-758

Brody JR and Cunha GR (1989a) Histologic, morphometric, and immunocytochemical analysis of myometrial development in rats and mice: 1 . Normal development American joumal of Anatomy 186 1-20

Brody JR and Cunha GR (1989b) Histologic, morphometric, and immunocytochernical analysis of myometrial development in rats and mice: II. Effects of DES on development American Jounal of Anatomy 186 21-42

Carlsson B and Billig H (1991) Insulin-like growth factor-I gene expression during development and estrous cycle in the rat uterus Molecular and Cellular Endocrinology 77 $175-180$

Carter DB. Newbold RR, Harris SE and McLachlan JA (1982) Molecular differentiation of the mouse genital tract: protein synthesis in fetal and immature female reproductive tract Biology of Reproduction 27 201-209

Christenson RK, Leymaster KA and Young LD (1987) Justification of unilateral hysterectomy-ovariectomy as a model to evaluate uterine capacity in swine Joumal of Animal Science 65 738-744

Christenson RK, Bartol FF, Vallet JL, Wiley AA and Spencer TE (1992) Comparative study of uterine morphogenesis and protein secretion in neonatal Meishan (Ms) and White crossbred $(\mathrm{Xb})$ pigs jounal of Animal Science 70 (Supplement 1) 264 (Abstract)

Cowley DE, Pomp D, Atchley WR, Eisen E] and Hawkins-Brown D (1989) The impact of matemal uterine genotype on postnatal growth and adult body size in mice Genetics 122 193-203

Cunha GR (1989) Development of the urogenital tract. In Handbook of Human Growh and Developnental Biology Vol. Il Part A pp 247-261 Ed. E Meisami and PS Timiras. CRC Press, Boca Raton

Cunha GR and lung B (1979) The importance of stroma in morphogenesis and functional activity of urogenital epithelium in Vitro 15 50-71

Cunha GR, Chung LWK, Shannon JM, Taguchi $O$ and Fujii $H$ (1983) Hormone-induced morphogenesis and growth: role of mesenchymal-epithelial interactions Recent Progress in Hormone Research 39 559-598

Cunha GR, Young P and Brody JR (1989) Role of uterine epithelium in the development of myometrial smooth muscle cells Biology of Reproduction 40 861-871

Daughaday WH and Rotwein P (1989) Insulin-like growth factors I and II. Peptide, messenger ribonucleic acid and gene structures, serum and tissue concentrations Endocrine Reviews 10 68-91

Davies J (1967) Comparative embryology. In Cellular Biology of the Uitens pp 13-32 Ed. RM Wynn. Appleton-Century Crofts, New York

De Luca LM (1991) Retinoids and their receptors in differentiation, embryogenesis, and neoplasia FASEB foumal 5 2924-2933

D'Ercole AJ, Stiles AD and Underwood LE (1984) Tissue concentrations of somatomedin C: further evidence for multiple sites of synthesis and paracrine or autocrine mechanisms of action Proceeding of the National Academy of Sciences USA $\mathbf{8 1}$ 935-939
Dyck GW (1980) Normal and abnormal development and puberty in gilts and boars. In Current Therapy in Theriogenology. pp 1 107-1112 Ed. D Morrow. Saunders Co., Philadelphia

Dyck GW and Swierstra EE (1983) Growth of the reproductive tract of the gilt from birth to puberty Canadian joumal of Animal Science 63 81-87

Dziuk PJ and Gehlbach GD (1966) Induction of ovulation and fertilization in the immature gilt joumal of Animal Science 25 $410-413$

Erices J and Schnurrbusch U (1979) Postnatal growth of the swine uterus from birth to age of eight months Archio fur Experimentelle Veterinamedizin 33 457-473

Ettinger L and Doljanski F (1992) On the generation of form by the continuous interactions between cells and their extracellular matrix Biological Reviews of the Cambridge Philosophical Society $67459-489$

Evans FD, Christopherson RJ and Aherne FX (1988) The comparative physiological development of the reproductive and adrenal axis of the gilt from weaning to puberty Canadian Joumal of Animal Science 68 1113-1119

First NL and Eyestone WH (1988) Reproductive efficiency in domestic animals Annals of the New York Academy of Science 541 697-705

Flaumenhaft $R$ and Rifkin DB (1991) Extracellular matrix regulation of growth factor and protease activity Current Opinion in Cell Biology 3 817-823

Forsberg JG (1988) Histogenesis of irteversible changes in the female genital tract after perinatal exposure to hormones and related substances. In Toxicily of Honmones in Perinatal Life PP 39-61 Ed. T Mori and H Nagasawa. CRC Press, Boca Raton

Hadek R and Getty R (1959) The changing morphology in the uterus of the growing pig American Joumal of Veterinary Research 20 573-577

Halling A and Forsberg JC (1990) Ovarian reproductive function after exposure to diethylstilbestrol in neonatal life Biology of Reproduction 43 472-477

Hayashi A, Donahoe PK, Budzik GP and Trelstad RL (1982) Periductal and matrix glycosaminoglycans in rat mutlerian duct development and regression Developmental Biology 92 16-26

Hofig A, Michel F, Simmen FA and Simmen RCM (1991) Constitutive expression of uterine receptors for insulin-like growth factor-I during the peri-implantation period in the pig Biology of Reproduction 45 533-539

lkeda T and Sirbasku DA (1984) Purification and properties of a mammary-uterine-pituitary tumor cell growth factor from pregnant sheep uterus Joumal of Biological Chemistry 259 4049-4064

Jackson RL, Busch SJ and Cardin AD (1991) Glycosarninoglycans: molecular properties, protein interactions, and role in physiological processes Physiological Revietos $7 \mathrm{t}$ 481-539

Kan M, Wang F, Xu J, Crabb JW, Hou J and McKeehan WL. (1993) An essential heparin-binding domain in the fibroblast growth factor receptor kinase Science 259 1918-1921

Katzenellenbogen BS (1979) Regulation of uterine responsiveness to estrogen. Developmental and multihormonal factors. In Ontogeny of Receptors and Reproductive Hormone Action PP 79-102 Ed. TH Hamilton, JH Clark and WA Sadler. Raven Press. New York

Kaye AM (1983) Sequential regulation of gene expression by estrogen in the developing rat uterus. In Regulation of Gene Expression by Honnones pp 103-128 Ed. KW McKerns. Plenum Press, New York 
Konishi l, Fujii S, Okamura H and Mori T (1984) Development of smooth muscle in the human fetal uterus: an ultrastructural study joumal of Anatomy 139 239-252

Lee CY, Bazer FW, Etherton TD and Simmen FA (1991) Ontogeny of insulin-like growth factors (IGF-I and ICF-II) and IGF-binding proteins in porcine serum during fetal and postnatal development Endocrinology 128 2336-2344

Legault C (1985) Selection of breeds, strains and individual pigs for prolificacy Joumal of Reproduction and Fertility Supplement 33 15T-166

Lund PK, Moats-Staats BM, Hynes MA, Simmons JG, Jansen M, D'Ercole AJ and Van Wyk JJ (1986) Somatomedin-C/insulinlike growth factor-1 and insulin-like growth factor-li mRNAs in rat fetal and adult tissues joumal of Biological Chemistry 26114 539-14 544

Maier DB, Newbold RR and McLachlan JA (1985) Prenatal diethylstilbestrol exposure alters murine uterine responses to prepubertal estrogen stimulation Endocrinology 116 $1878-1886$

Marion GB and Gier HT (1971) Ovarian and uterine embryogenesis and morphology of the non-pregnant female mammal Joumal of Animal Science 32 (Supplement 1) 24-47

Medlock KL, Sheehan DM, Nelson CJ and Branham WS (1988) Effects of postnatal DES treatment on uterine growth, development, and estrogen receptor levels joumal of Steroid Biochemistry 29 527-532

Mori T and Iguchi T (1988) Long-term effects of perinatal treatment with sex steroids and related substances on reproductive organs of female mice. In Toxicity of Honnones in Perinatal Life pp 63-79 Ed. T Mori and H Nagasawa. CRC Press, Boca Raton

Mossman HW (1980) Comparative morphology of the endometrium. In The Endometrium pp 3-23 Ed. FA Kimball. Spectrum Publications Inc., New York

Mossman HW (1989) Comparative anatomy. In Biology of the Utenis pp 19-34 Ed. RM Wynn and WP Jollie. Plenum Medical, New York

Murphy LJ and Ghahary A (1990) Uterine insulin-like growth factor-1: regulation of expression and its role in estrogen. induced uterine proliferation Endocrine Revietos 11 443-453

Newbold RR, Carter DB, Harris SE and McLachlan JA (1984) Molecular differentiation of the mouse genital tract: altered protein synthesis following exposure to diethylstilbestrol Biology of Reproduction 30 459-470

Ogasawara Y, Okamoto S, Kitamura Y and Matsumoto K (1983) Proliferative patterns of uterine cells from birth to adulthood in intact, neonatally castrated, and/or adrenalectomized mice, assayed by incorporation of ['25] iododeoxyuridine Endocrinology $113582-587$

Padykula HA, Coles LG, McCracken JA, King NW, Jr, Longcope C and Kaiserman-Abramof IR (1984) Axonal pattern of cell proliferation and differentiation in the rhesus endometrium during the estrogen surge Biology of Reproduction 31 1103-1118

Padykula HA, Coles LG, Okulicz WC, Rapaport Sl, McCracken JA, King NW Jr, Longcope C and Kaiserman-Abramof IR (1989) The basalis of the primate endometrium: a bifunctional germinal compartment Biology of Reproduction $\mathbf{4 0}$ $681-690$

Pasqualini JR and Sumida C (1986) Ontogeny of steroid receptors in the reproductive system International Review of Cytology $101275-324$

Pervaiz S and Brew K (1987) Homology and structure-function correlations between $\alpha_{\mathrm{t}}$-acid glycoprotein and serum retinolbinding protein and its relatives FASEB joumal 1 209-214
Pomp D, Cowley DE, Eisen EJ, Atchley WR and Hawkins-Brown D (1989) Donor and recipient genotype and heterosis effects on survival and prenatal growth of transferred mouse embryos Jounal of Reproduction and Fertility 86 493-500

Reynolds LP, Killilea SD and Redmer DA (1990) Characterization of heparin-binding endothelial mitogen(s) produced by ovine endometrium during early pregnancy joumal of Animal Science 68 (Supplement I) 443 (Abstract)

Roberts RM and Bazer FW (1988) The function of uterine secretions Joumal of Reproduction and Fertility 82 875-892

Sananes NE, Baulieu EE and LeCoascogne C (1980) Treatment of neonatal rats with progesterone alters the capacity of the uterus to form deciduomata Joumal of Reproduction and Fertility 58 271-273

Sanders EJ (1988) The roles of epithelial-mesenchymal cell interactions in developmental processes Biochemistry and Cell Biology $66530-540$

Schubert D (1992) Collaborative interactions between growth factors and the extracellutar matrix Trends in Cell Biology 2 63-66

Schubert $D$ and LaCorbiere $M$ (1986) $A$ chick neural retina adhesion and survival molecule is a retinol-binding protein Joumal of Cell Biology 102 2295-2301

Sharpe PM and Ferguson MWJ (1988) Mesenchymal influences on epithelial differentiation in developing systems joumal of Cell Science (Supplement) 10 195-230

Silberstein GB and Daniel CW (1982) Glycosaminoglycans in the basal lamina and extracellular matrix of the developing mouse mammary gland Developmental Biology $90215-222$

Simmen RCM and Simmen FA (1990) Regulation of uterine and conceptus secretory activity in the pig Joumal of Reproduction and Ferfility 40 279-292

Simmen RCM, Ko Y, Lui XH, Wilde MH, Pope WF and Simmen FA (1988) A uterine cell mitogen distinct from epidermal growth factor in porcine uterine luminal fluids: characterization and partial purification Biology of Reproduction 38 551-561

Simmen FA, Simmen RCM, Letcher LR, Schober DA and Ko Y (1989a) IGFs in pregnancy: developmental expression in uterus and mammary gland and paracrine actions during embryonic and neonatal growth. In Molecular and Cellular Biology of insulin-Like Growth Factors and Their Receptors pp 195-208 Ed. D LeRoith and MK Raizada. Plenum Publishing Co.. New York

Simmen RCM. Simmen FA, Ko Y and Bazer FW (1989b) Differential growth factor content of uterine luminal fluids from Large White and prolific Meishan pigs during the estrous cycle and early pregnancy Joumal of Animal Science 67 1538-1545

Simmen RCM, Simmen FA, Hofig A, Farmer SJ and Bazer FW (1990) Hormonal regulation of insulin-like growth factor gene expression in pig utenus Eudocrinology 127 21662174

Simmen FA, Simmen RCM, Geisert RD, Martinat-Botte F, Bazer FW and Terqui M (1991) Differential expression, during the estrous cycle and pre- and postimplantation conceptus development, of messenger ribonucleic acids encoding components of the pig uterine insulin-like growth factor system Endocrinology 130 1547-1556

Spencer TE, Bartol FF, Simmen RCM, Wiley AA, Bryan BO and Coleman DA (1992a) Effects of neonatal age and period of estrogen exposure on porcine uterine growth, uterine IGF-I gene expression and peripheral plasma IGF-I concentrations jounul of Animal Science 70 (Supplement 1) 264 (Abstract) 
Spencer TE, Wiley AA and Bartol FF (1992b) Lectin binding sites as markers of neonatal porcine uterine development foumal of Histochemistry and Cytochemistry 40 1937-1942

Spencer TE, Bartol FF, Wiley AA, Coleman DA and Wolfe DF (1993a) Neonatal porcine endometrial development involves coordinated changes in DNA synthesis, glycosaminoglycan distribution, and ${ }^{3} \mathrm{H}-$ glucosamine labeling Biology of Reproduction 48 729-740

Spencer TE, Wiley AA and Bartol FF (1993b) Neonatal age and period of estrogen exposure affect porcine uterine growth, morphogenesis, and protein synthesis Biology of Reproduction 48 741-750

Spicer SS and Schulte BA (1992) Diversity of cell glycoconjugates shown histochemically: a perspective jountal of Histochemistry and Cytochemistry 40 1-38

Spooner BS and Thompson-Pletscher HA (1986) Matrix accumulation and the development of form: proteoglycans and branching morphogenesis. In Regulation of Malrix Accumulation pp 399-444 Ed. RP Mecham. Academic Press. Orlando

Stockard CR (1921) Developmental rate and structural expression: an experimental study of twins, 'double monsters' and single deformities and the interaction among embryonic organs during their development American joumal of Anatomy 28 115-263

Sugimura Y, Cunha GR, Donjacour AA, Bigsby RM and Brody JR (1986) Whole-mount autoradiography study of DNA synthetic activity during postnatal development and androgen-induced regeneration in the mouse prostate Biology of Reproduction 34 985-995

Taguchi O. Bigsby RM and Cunha GR (1988) Estrogen responsiveness and the estrogen receptor during the development of the murine female reproductive tract Development. Growth and Differentiation 30 301-314

Tavakkol A, Simmen FA and Simmen RCM (1988) Porcine insulin-like growth factor-I (pIGF-l): a complementary deoxyribonucleic acid cloning and uterine expression of messenger ribonucleic acid encoding evolutionarily conserved IGF-I peptides Molecular Endocrinology 2 674-681

Toole BP (1991) Proteoglycans and hyaluronan in morphogenesis and differentiation. In Cell Biology of Extracellular Matrix pp 305-342 Ed. ED Hay, Plenum Press. New York

Trout WE, Hall JA, Stallings-Mann ML. Galvin JM, Anthony RV and Roberts RM (1992) Steroid regulation of the synthesis and secretion of retinol-binding protein by the utenus of the pig Endocrinology 130 2557-2564

Vallet JL. Christenson RK and Bartol Ff (1992) Increased secretion of a retinol binding protein-like protein is temporally associated with initiation of uterine gland development joumal of Animal Science 70 (Supplement 1) 264 (Abstract)

- Wedden SE (1987) Epithelial-mesenchymal interactions in the development of chick facial primordia and the target of retinoid action Development 99 341-351

Wegner CC and Carson DD (1992) Mouse uterine stromal cells secrete a 30-kilodalton protein in response to coculture with uterine epithelial cells Endocrinology 131 2565-2572

Wiley AA, Bartol FF and Barron DH (1987) Histogenesis of the ovine uterus Joumal of Animal Srience 64 1262-1269

Wiley AA, Spencer TE and Bartol FF (1992) in vitro metabolic labeling of uterine tissues with $\mathrm{D}-16-{ }^{3} \mathrm{H} \mid \mathrm{g}$ lucosamine for in situ or chromatographic assessment of glycosaminoglycan biosynthesis. In Hanibook of Methods for Study of Reproductive Physiology in Domestic Animals Section VII. A. Ed. $P$ Dziuk and $M$ Wheeler. University of Illinois, Champaign

Wu MC and Dziuk PJ (1988) Ovarian influence on uterine growth in prepubertal pigs Joumal of Animal Science 66 2893-2898

Zapf J and Froesch ER (1986) Insulin-like growth factors/ somatomedins: structure, secretion, biological action and physiological role Hormone Research 24 121-130 